\title{
A COMPARATIVE STUDY OF CHROMOSOMAL POLY- MORPHISM IN CERTAIN SOUTH AMERICAN SPECIES OF DROSOPHILA
}

\author{
A. BRITO DA CUNHA, DANKO BRNCIC, and F. M. SALZANO \\ University of Sro Paulo, University of Chile, and \\ University of Rio Grande do Sul
}

Received 12.ix.52

\section{INTRODUCTION}

NATURAL populations of most species of Drosophila are variable with respect to the gene arrangement in the chromosomes of different individuals. In some species, a considerable proportion of flies found in nature are inversion heterozygotes. The degree of the variability of the chromosome structure varies however in geographic races of the same species, as well as in different species. To account for the different variability of different races and species, da Cunha, Burla and Dobzhanksy (1950), and Dobzhansky, Burla and da Cunha (1950) have advanced the following working hypothesis. Since the chromosomal polymorphism in Drosophila populations is adaptive and balanced, the amount of this polymorphism present in a race or a species is likely to be a function of the number and variety of the ecological niches which the population has mastered. Other things being equal, species which exploit many different kinds of food, or which occur in many different biotopes, are likely to exhibit a greater degree of adaptive polymorphism than do species which are specialised to exploit only a limited variety of adaptive opportunities.

The data reported in the present paper have been collected in order to submit the above working hypothesis to further tests. We have chosen several species of Drosophila which are favourable for studies on the chromosomes in the larvæ salivary glands. The amounts of the chromosomal variability were then compared either in pairs of closely related species, or in different populations of the same species. The data so obtained can be evaluated against the background of the ecological characteristics of the respective races and species described by Dobzhansky and Pavan (1950), Pavan (unpublished), and Cordeiro (unpublished).

\section{METHODS}

Single females collected in nature were allowed to produce offspring in individual cultures with banana-agar nutrient medium. The salivary glands of mature larvæ produced in the cultures were stained with acetic orcein. The chromosomes of a single larva in the offspring of each wild progenitor were then examined. 


\section{DROSOPHILA POLYMORPHA AND DROSOPHILA CARDINOIDES}

$D$. polymorpha Dobzhansky and Pavan and D. cardinoides Dobzhansky and Pavan are closely related species belonging to the cardini species group of the Subgenus Drosophila. They are sympatric in a large area, which extends, as far as known, from northern Argentina to Central America. The metaphase chromosome groups of both species are alike; they contain two pairs of metacentric autosomes (the second and the third), a pair of acrocentric X-chromosomes, and a pair of dot-like autosomes. The inversions found in these chromosomes are described by da Cunha and Salzano (in press).

TABLE I

Frequencies (in per cent.) of various inversions found in heterozygous condition, and the mean numbers of heterozygous inversions per individual in $\mathrm{D}$. polymorpha

\begin{tabular}{|c|c|c|c|c|}
\hline Chromosome & Inversions & $\begin{array}{c}\text { Vila } \\
\text { Atlantica }\end{array}$ & Pirassununga & $\begin{array}{c}\text { Mogf das } \\
\text { Cruzes }\end{array}$ \\
\hline II & $\left\{\begin{array}{c}\text { none } \\
A a\end{array}\right.$ & $\begin{array}{l}71 \cdot 6 \\
28 \cdot 4\end{array}$ & $\begin{array}{r}98 \cdot 8 \\
1 \cdot 2\end{array}$ & $\begin{array}{r}98 \cdot 7 \\
1 \cdot 3\end{array}$ \\
\hline III & $\left\{\begin{array}{c}\text { none } \\
A a \\
B b\end{array}\right.$ & $\begin{array}{r}92 \cdot 5 \\
7 \cdot 5 \\
7 \cdot 5\end{array}$ & $\begin{array}{l}100 \\
\cdots \\
\cdots\end{array}$ & $\begin{array}{l}100 \\
\ldots \\
\cdots\end{array}$ \\
\hline $\mathrm{x}$ & $\left\{\begin{array}{c}\text { none } \\
A a \\
B b \\
C c\end{array}\right.$ & $\begin{array}{l}43 \cdot 3 \\
43 \cdot 3 \\
56 \cdot 7 \\
43 \cdot 3\end{array}$ & $\begin{array}{c}63 \cdot 6 \\
36 \cdot 4 \\
36 \cdot 4 \\
\quad \ldots\end{array}$ & $\begin{array}{l}82.5 \\
17.5 \\
17.5 \\
17.5\end{array}$ \\
\hline \multirow{2}{*}{ Mean per individu } & \multirow{2}{*}{ la } & $0.46 \pm 0.08$ & $0.0 I$ & 0.01 \\
\hline & & $I \cdot 82 \pm 0 \cdot 18$ & $I \cdot I 0 \pm 0 \cdot I 6$ & $0.54 \pm 0 \cdot 14$ \\
\hline \multirow{2}{*}{ Flies tested $\left\{\begin{array}{l}\sigma^{\pi} \\
o\end{array}\right.$} & \multirow{2}{*}{$\begin{array}{l}\cdot \quad \cdot \\
\cdot \quad .\end{array}$} & 67 & 83 & 93 \\
\hline & & 67 & 88 & 63 \\
\hline
\end{tabular}

The chromosomal polymorphism in $D$. polymorpha is greater than that in $D$. cardinoides. In the former species, six different inversions have been found in $46 \mathrm{r}$ wild individuals collected in three localities, while in $D$. cardinoides three inversions were found in $14 \mathrm{I}$ flies, also from three localities. More important are the data on the frequencies of heterozygosis for inversions in the populations of the two species, summarised in tables $I$ and 2.

Sufficient samples of $D$. polymorpha were available from three localities in the State of São Paulo, Brazil, namely Vila Atlantica, Pirassununga, and Mogí das Cruzes. The mean numbers of heterozygous inversions, per female, were $\mathrm{I} \cdot 82, \mathrm{I} \cdot \mathrm{IO}$ and 0.54 in the three localities. The mean numbers in the males are lower, since no 
inversion heterozygosis can be detected in the $\mathrm{X}$-chromosome in the males.

Samples of $D$. cardinoides were studied from Vila Atlantica (State of São Paulo), from Cantareira (same State, about $50 \mathrm{~km}$. from Mogí das Cruzes), and from Catuní (State of Bahia). In all these samples the inversions proved to be rare. The numbers of heterozygous inversions per individual were 0.06 , 0 and 0.05 in the three localities respectively.

$D$. polymorpha is a species which is relatively more common, at least in southern Brazil, than D. cardinoides. At Pirassununga, the frequencies of $D$. polymorpha vary from 0.2 to 22 per cent. of the total catch of all species of Drosophila, depending upon season. $D$. cardinoides is much less frequent, varying from 0.03 to 0.5 per cent.

TABLE 2

Frequencies (in per cent.) of various inversions found in heterozygous condition, and the mean numbers of heterozygous inversions per individual in D. cardinoides

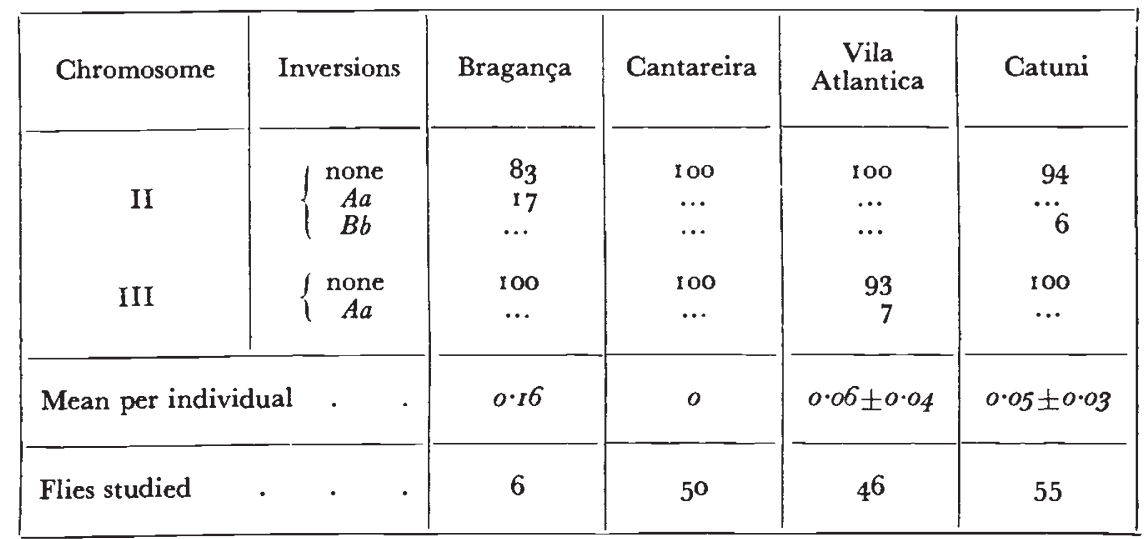

of the total catch. At Mogí das Cruzes, D. polymorpha varies from 0.9 to 22 per cent., and $D$. cardinoides from 0.01 to 3.5 per cent. of all Drosophila. At Vila Atlantica, from 0.2 to 3 per cent. of the flies are $D$. polymorpha and O.I to 4.3 per cent. are $D$. cardinoides. It should be noted that the high proportions of $D$. cardinoides have been observed close to human habitations, and the proportions in undisturbed localities are always below I per cent. Similarly, at Cantareira and at Catuní, $D$. cardinoides has been collected only in orchards, near human habitations. $D$. polymorpha is a species which we have not collected under such conditions.

\section{DROSOPHILA GUARAMUNU AND DROSOPHILA GRISEOLINEATA}

D. guaramunu Dobzhansky and Pavan and D. griseolineata Duda are closely related to each other, and both of them belong to the guarani species group of the subgenus Drosophila (King, 1947). Their known distribution regions extend from northern Argentine to central 
Brazil. In both species, the metaphase chromosome plates contain five pairs of rod-shaped and one pair of dot-like chromosomes. A total of 16 kinds of inversions have been found in the offspring of 896 wild individuals of $D$. guaramunu from seven different localities. A description of these inversions can be found in the paper of Brncic (in press). In $D$. griseolineata, 5 kinds of inversions have been encountered in the offspring of $6 \mathrm{I}_{2}$ wild flies from six localities. These inversions are to be described by Salzano (unpublished).

TABLE 3

Frequencies (in per cent.) of various inversions in heterozygous condition, and the mean numbers of heterozygous inversion per individual of $\mathrm{D}$. guaramunu

\begin{tabular}{|c|c|c|c|c|c|c|c|c|}
\hline $\begin{array}{l}\text { Chromo- } \\
\text { some }\end{array}$ & $\begin{array}{l}\text { Inver- } \\
\text { sions }\end{array}$ & Chapada & $\begin{array}{l}\text { Ponta } \\
\text { Grossa }\end{array}$ & Itapoan & Feliz & Bragança & $\begin{array}{l}\text { Mogí das } \\
\text { Cruzes }\end{array}$ & $\begin{array}{c}\text { Piras- } \\
\text { sununga }\end{array}$ \\
\hline II & $\left\{\begin{array}{c}\text { None } \\
A a\end{array}\right.$ & $\begin{array}{l}60 \cdot 8 \\
39 \cdot 2\end{array}$ & $\begin{array}{l}56 \cdot 4 \\
43 \cdot 6\end{array}$ & $\begin{array}{l}60 \cdot 0 \\
40 \cdot 0\end{array}$ & $\begin{array}{l}4^{8 \cdot} \cdot 5 \\
5^{1} \cdot 5\end{array}$ & $\begin{array}{l}45^{\circ} 0 \\
55^{\circ} 0\end{array}$ & $\begin{array}{l}50 \cdot 8 \\
49^{\cdot 2}\end{array}$ & $\begin{array}{l}47 \cdot 5 \\
52 \cdot 5\end{array}$ \\
\hline III & $\left\{\begin{array}{c}\text { None } \\
A a \text { or } B b \\
A a B b\end{array}\right.$ & $\begin{array}{c}43 \cdot 4 \\
56 \cdot 6 \\
\ldots\end{array}$ & $\begin{array}{l}4 \mathrm{I} \cdot 8 \\
47 \cdot 1 \\
10 \cdot 9\end{array}$ & $\begin{array}{c}50 \cdot 0 \\
50 \cdot 0 \\
\ldots\end{array}$ & $\begin{array}{r}5^{\mathrm{I}} \cdot 5 \\
4^{\mathrm{I}} \cdot 0 \\
7 \cdot 5\end{array}$ & $\begin{array}{r}45 \cdot 0 \\
5 \cdot \cdot 0 \\
5 \cdot 0\end{array}$ & $\begin{array}{r}49 \cdot 2 \\
43 \cdot 4 \\
7 \cdot 4\end{array}$ & $\begin{array}{r}47 \cdot 9 \\
47 \cdot 9 \\
4 \cdot 1\end{array}$ \\
\hline IV & $\left\{\begin{array}{l}\text { None } \\
A a \\
B b \\
C c \\
D d \\
E e \\
F f \\
G g \\
H h \\
I i \\
\not j \\
K k \\
L l \\
M m\end{array}\right.$ & $\begin{array}{c}32 \cdot 6 \\
19 \cdot 5 \\
15 \cdot 1 \\
\ldots \\
1 \cdot 1 \\
15 \cdot 1 \\
\ldots \\
4 \cdot 3 \\
14 \cdot 1 \\
5 \cdot 4 \\
5 \cdot 4 \\
5 \cdot 4 \\
5 \cdot 4 \\
\ldots\end{array}$ & $\begin{array}{c}74 \cdot 5 \\
3 \cdot 6 \\
10 \cdot 9 \\
\ldots \\
\ldots \\
14 \cdot 5 \\
\ldots \\
3 \cdot 6 \\
14 \cdot 5 \\
\ldots \\
\ldots \\
\ldots \\
\ldots \\
\ldots\end{array}$ & $\begin{array}{c}30 \cdot 0 \\
10 \cdot 0 \\
\ldots \\
\ldots \\
\ldots \\
30 \cdot 0 \\
\ldots \\
\ldots \\
30 \cdot 0 \\
\ldots \\
\ldots \\
\ldots \\
\ldots\end{array}$ & $\begin{array}{c}30 \cdot 3 \\
21 \cdot 2 \\
18 \cdot 1 \\
\ldots \\
4 \cdot 5 \\
36 \cdot 2 \\
\cdots \\
1 \cdot 5 \\
31 \cdot 8 \\
\cdots \\
\ldots \\
\ldots \\
\ldots \\
\ldots\end{array}$ & $\begin{array}{c}30 \cdot 0 \\
25 \cdot 0 \\
25 \cdot 0 \\
\ldots \\
5 \cdot 0 \\
30 \cdot 0 \\
\ldots \\
10 \cdot 0 \\
30 \cdot 0 \\
20 \cdot 0 \\
20 \cdot 0 \\
20 \cdot 0 \\
20 \cdot 0 \\
\ldots\end{array}$ & $\begin{array}{l}49 \cdot 2 \\
25 \cdot 4 \\
19: 7 \\
\ldots \\
0 \cdot 8 \\
0 \cdot 8 \\
\ldots \\
6 \cdot 5 \\
0 \cdot 8 \\
1 \cdot 7 \\
1 \cdot 7 \\
1 \cdot 7 \\
1 \cdot 7 \\
1 \cdot 7\end{array}$ & $\begin{array}{r}40 \cdot 1 \\
20 \cdot 6 \\
15 \cdot 2 \\
0 \cdot 2 \\
2 \cdot 4 \\
13 \cdot 9 \\
0 \cdot 4 \\
3 \cdot 7 \\
12 \cdot 6 \\
5 \cdot 6 \\
5 \cdot 6 \\
5 \cdot 6 \\
5 \cdot 6 \\
\ldots\end{array}$ \\
\hline \multicolumn{2}{|c|}{$\begin{array}{l}\text { Mean per } \\
\text { individual }\end{array}$} & $2 \cdot 13 \pm 0 \cdot 13$ & $r \cdot 65 \pm 0 \cdot 14$ & $x \cdot 60 \pm 0.38$ & $2 \cdot 18 \pm 0 \cdot 17$ & $3 \cdot 20 \pm 0.46$ & $I .66 \pm 0.09$ & $2 \cdot 00 \pm 0.06$ \\
\hline \multicolumn{2}{|c|}{ Flies tested } & 92 & 55 & 10 & 66 & 20 & $19^{2}$ & $4^{6} \mathrm{I}$ \\
\hline
\end{tabular}

The frequencies of the various inversions in the population samples studied are summarised in tables 3 and 4 . It can be seen at a glance that the chromosomal variability is much greater in $D$. guaramunu than in $D$. griseolineata. In the former species, the localities in the State of Rio Grande do Sul (Chapada, Ponta Grossa, Itapoan and Feliz) have between $I \cdot 6$ and $2 \cdot 2$ inversions per individual. In the State of São Paulo (Bragança, Mogi das Cruzes, Pirassununga) the inversion frequencies are about the same as in Rio Grande do Sul ( $1 \cdot 7$ to $3 \cdot 2$, the latter figure being subject to a large error). Since no inversions have been detected in the $\mathrm{X}$-chromosome of these 
species, the data for females and males can be combined. In $D$. griseolineata, the State of Rio Grande do Sul (Ponta Grossa, Itapoan, Emboaba) shows perhaps fewer inversions per individual than does the State of São Paulo (Vila Atlantica, Cantareira, and Mogí das Cruzes). But even the highest recorded inversion frequency per individual of $D$. griseolineata $(0.47, c f$. table 4$)$ is lower than the lowest frequency found in $D$. guaramunu $(\mathrm{x} \cdot 6, c f$. table 3$)$.

According to Dobzhansky and Pavan (1950), D. guaramunu is more common and widespread in Brazil than is D. griseolineata. The former species proved to be one of the commonest species of Drosophila in 5 out of the 35 localities studied by these authors. The latter species

\section{TABLE 4}

Frequencies (in per cent.) of various inversions found in heterozygous condition, and the mean numbers of heterozygous inversion per individual of D. griseolineata

\begin{tabular}{|c|c|c|c|c|c|c|c|}
\hline $\begin{array}{l}\text { Chromo- } \\
\text { some }\end{array}$ & $\begin{array}{l}\text { Inver- } \\
\text { sions }\end{array}$ & $\begin{array}{l}\text { Ponta } \\
\text { Grossa }\end{array}$ & Itapoan & Emboaba & $\begin{array}{c}\text { Vila } \\
\text { Atlantica }\end{array}$ & Cantareira & $\begin{array}{l}\text { Mogí das } \\
\text { Cruzes }\end{array}$ \\
\hline II & $\begin{array}{c}\text { none } \\
A a \\
B b \\
C c\end{array}$ & $\begin{array}{c}96 \cdot 5 \\
\ldots \\
3 \cdot 5 \\
\ldots\end{array}$ & $\begin{array}{c}97 \cdot 1 \\
\ldots \\
2 \cdot 9 \\
\ldots\end{array}$ & $\begin{array}{l}98 \cdot 6 \\
\cdots \\
\ldots \cdot 4 \\
\ldots\end{array}$ & $\begin{array}{r}80 \cdot 8 \\
1 \cdot 1 \\
14 \cdot 0 \\
4 \cdot 1\end{array}$ & $\begin{array}{c}90 \cdot 6 \\
\dddot{8} \\
1 \cdot 0 \\
1 \cdot 4\end{array}$ & $\begin{array}{r}82 \cdot 9 \\
2 \cdot 6 \\
9 \cdot 2 \\
5 \cdot 3\end{array}$ \\
\hline III & $\begin{array}{c}\text { none } \\
A a \\
B b\end{array}$ & $\begin{array}{r}94 \cdot 7 \\
5 \cdot 3 \\
5 \cdot 3\end{array}$ & $\begin{array}{c}100 \cdot 0 \\
\ldots \\
\ldots\end{array}$ & $\begin{array}{c}100 \cdot 0 \\
\ldots \\
\ldots\end{array}$ & $\begin{array}{l}86.4 \\
\times 3.6 \\
\times 3.2\end{array}$ & $\begin{array}{l}81 \cdot 0 \\
19 \cdot 0 \\
19 \cdot 0\end{array}$ & $\begin{array}{l}86 \cdot 8 \\
14 \cdot 0 \\
14.0\end{array}$ \\
\hline \multicolumn{2}{|c|}{ Mean per individual } & $0.14 \pm 0.06$ & $0.02 \pm 0.06$ & $0.0 I \pm 0.04$ & $0.47 \pm 0.04$ & $0.47 \pm 0.09$ & $0.4^{6} \pm 0.09$ \\
\hline \multicolumn{2}{|c|}{ Flies tested } & 57 & 69 & $7^{1}$ & 265 & 74 & 76 \\
\hline
\end{tabular}

has been found in 6 out of the 35 localities, but in all of them it was one of the rarer forms. D. guaramunu is, indeed, one of the dominant species both in the savanna of central Brazil and in the subtropical forest of the State of Rio Grande do Sul. At Pirassununga, which represents ecologically a southern outlier of the savanna of central Brazil, the lowest frequency of $D$. guaramunu in 18 different collections made during four years of observation was about 2 per cent., and in 9 of these collections it was above 18 per cent., of the total catch of Drosophila flies. At Mogí das Cruzes, its frequency varied from o to 23 per cent. of the total, and at Vila Atlantica from o to 6 per cent. of the total. In Rio Grande do Sul, D. guaramunu is encountered with frequencies from 0.5 to 5 per cent. on the coast, and from in to $5^{\mathrm{I}}$ per cent. in the interior of the State.

$D$. griseolineata varies greatly in frequency, but it is on the whole much less common than $D$. guaramunu. The recorded frequencies of the former species vary from o to 30 per cent. at Vila Atlantica and 
from o to 16 per cent. at Mogí das Cruzes. In Rio Grande do Sul, this species is relatively more common on the coast ( 2 to 30 per cent.) than in the interior, where it is quite rare. Furthermore, the frequencies of this species are subject to violent fluctuations at different seasons.

\section{DROSOPHILA NEBULOSA}

Drosophila nebulosa Sturtevant is a member of the willistoni species group of the subgenus Sophophora. Its distribution region extends from Texas in the North (Patterson and Wagner, I943) to at least Buenos Aires in the South (Pavan, unpublished). No Drosophila collecting has ever been made south of Buenos Aires. In Brazil, $D$. nebulosa is one of the commonest species, particularly in drier savanna and desert regions, less common in the rain forests. Furthermore, the frequencies of $D$. nebulosa relative to those of other species of Drosophila tend to be higher during the warmer and drier than during the wetter and cooler seasons (Pavan, unpublished).

The metaphase plates of $D$. nebulosa show two pairs of metacentric and one pair of acrocentric chromosomes. Pavan (1946) examined the salivary gland chromosomes of a series of strains, and described 9 inversions, all but one of which were found in a single chromosome, the third, which is the acrocentric autosome. In our material, we have observed 7 out of the 8 inversions described by Pavan in the third chromosome, and found 3 new inversions, namely $I i, \mathcal{F}$, and $K k$, also in the third chromosome. The single inversion found by Pavan in the X-chromosome was not found in our material.

The frequencies of the inversion heterozygosis in the populations examined by ourselves are given in table 5. Only the gene arrangements $H H, H h$ and $h h$ were identified both when homozygous and when heterozygous. The inversions $A a, B b, C c, G g$ and $H h$ occur frequently in all the regions studied; the inversions $E e, F f, I i, Z j$ and $K k$ are less common or restricted to only small fractions of the species distribution area.

It may be noted that a group of populations comprising Mucajai, Monjolinho, Pirassununga, Iguassú and Tucuman show high frequencies of the gene arrangement $h$, while Rio Negro, Imperatriz, Salitre and Catuní are characterised by high frequencies of the alternative gene arrangement, $H$. This distribution of the frequencies of $h$ and $H$ shows no clear correlations with the ecological characteristics of the localities in which the respective samples were collected. Thus, Mucajaí is more similar to Monjolinho, some $2500 \mathrm{~km}$. away, than it is to Rio Negro, less than $500 \mathrm{~km}$. away. Mucajaí, Iguassú and Rio Negro are covered with rain forest, while the other localities have savanna or desert vegetation.

The mean frequencies of the numbers of heterozygous inversions per individual show, on the contrary, a fairly clear correlation with the ecological characteristics of the regions in which the population 


\begin{tabular}{|c|c|c|c|c|c|}
\hline 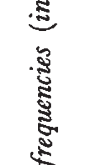 & : & 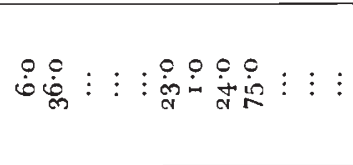 & $\begin{array}{l}\infty \\
0 \\
\dot{0} \\
+1 \\
0 \\
0\end{array}$ & 8 & $\stackrel{m}{\circ}$ \\
\hline 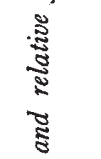 & 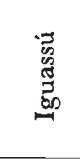 & 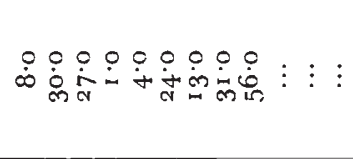 & $\begin{array}{l}\infty \\
\vdots \\
\dot{5} \\
+1 \\
1 \\
\stackrel{9}{i}\end{array}$ & 8 & $\begin{array}{l}\infty \\
\dot{\infty}\end{array}$ \\
\hline 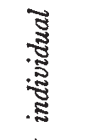 & 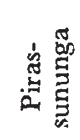 & 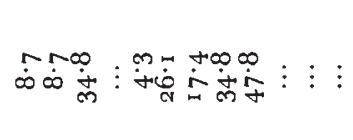 & $\hat{\vec{i}}$ & $\tilde{\sigma}$ & $\frac{\sigma}{\mathfrak{s}}$ \\
\hline 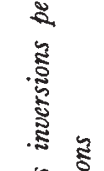 & 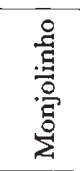 & कृष् & 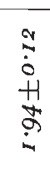 & $\mathscr{6}$ & $\begin{array}{l}\infty \\
\dot{\alpha} \\
\stackrel{0}{1} \\
\stackrel{1}{1} \\
i\end{array}$ \\
\hline 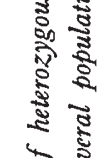 & 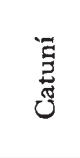 & 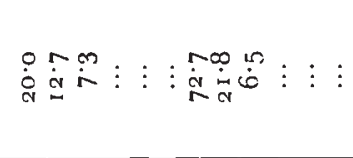 & $\begin{array}{l}8 \\
\dot{0} \\
\dot{H} \\
\dot{0} \\
\dot{0}\end{array}$ & น & $\hat{\dot{\theta}}$ \\
\hline 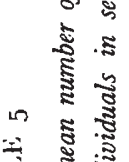 & 氙菏 & 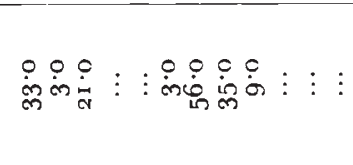 & $\begin{array}{l}2 \\
\dot{0} \\
+1 \\
8 \\
0\end{array}$ & ¿ & $\stackrel{m}{\dot{H}}$ \\
\hline 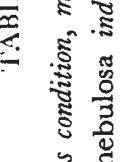 & 壱寄 & 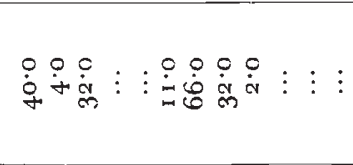 & $\begin{array}{l}\overline{1} \\
\dot{0} \\
+1 \\
\dot{9} \\
\dot{i}\end{array}$ & $\stackrel{8}{8}$ & $\dot{\text { in }}$ \\
\hline 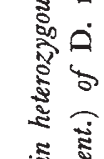 & 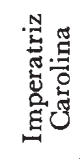 & 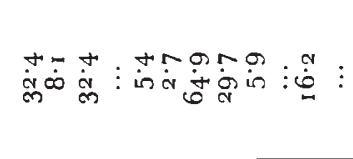 & $\begin{array}{l}c \\
\dot{c} \\
+1 \\
\tilde{\omega} \\
i\end{array}$ & $\hat{m}$ & $\stackrel{\infty}{i}_{\mathfrak{L}}$ \\
\hline 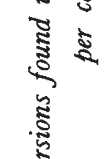 & 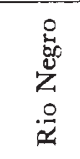 & 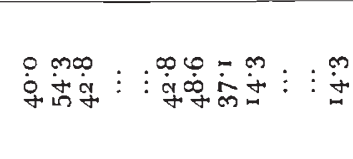 & $\begin{array}{l}5 \\
\dot{0} \\
+ \\
\hat{9} \\
\dot{\sigma}\end{array}$ & $\stackrel{m}{m}$ & $\stackrel{\infty}{\stackrel{\sim}{\sim}}$ \\
\hline 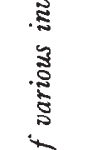 & 菏 & $\dot{\infty}$ & $\begin{array}{c}9 \\
i \\
i \\
0 \\
0 \\
\dot{c}\end{array}$ & हे & $\stackrel{0}{\dot{5}}$ \\
\hline 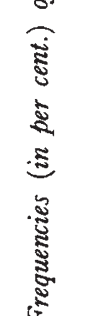 & 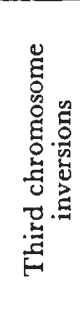 & $\begin{array}{c}\cdots \\
\cdots \\
\ldots \ldots\end{array} \ldots \ldots \ldots$ & 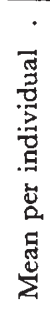 & 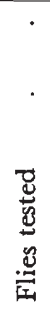 & 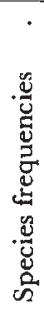 \\
\hline
\end{tabular}


samples were taken. The highest frequencies are observed at Mucajai, Rio Negro, Monjolinho, and Imperatriz. The first and the second of these localities are covered with exuberant rain forests, but are close to margins of savannas. On Rio Negro in particular, D. nebulosa proved to be commoner in drier localities than in wetter ones (up to 50 per cent. of the total catch of Drosophila flies on the beach of Tatuaquara, near Manaus). Monjolinho and Imperatriz lie in ecologically highly complex regions, on or near the ecotones between the savanna and the rain forest, or gallery forest, vegetations. By contrast, Salitre and Catuni, which show low frequencies of inversions, are in a desert (caatinga) region, which is dry and nearly lifeless during more than six months per year. Although $D$. nebulosa is the commonest species of Drosophila in this desert, it certainly can occupy there only a very limited number of ecological niches. It should be noted that $D$. willistoni has also shown the lowest numbers of heterozygous inversions per individual in this region (da Cunha, Burla and Dobzhansky, 1950). Finally, Tucuman lies at the foot of the Andes, presumably near the margin of the distribution area of the species. The population sample was collected there in an isolated forested region having a limited variety of plant species.

\section{DROSOPHILA BANDEIRANTORUM AND DROSOPHILA PALLIDIPENNIS}

Drosophila bandeirantorum Dobzhansky and Pavan and D. pallidipennis Duda are species with no clear affinities among the known species of Drosophila. The former has a rather restricted known geographic distribution area in southern Brazil. The latter has been recorded from the State of São Paulo, in southern Brazil, as well as from Mexico, but has so far not been encountered in the Amazon Basin. Both species are fairly rare, and appear to be specialised to occupy a restricted variety of ecological niches (Dobzhansky and Pavan, i 950). Their salivary gland chromosomes are among the best found in any species of Drosophila, and this served as a stimulus to study them for inversions.

In $44^{\mathrm{I}}$ examined individuals of $D$. bandeirantorum, two kinds of inversions were found, one in each, the second and the third chromosomes (autosomes). In D. pallidipennis, Patterson and Dobzhansky (1945), Freire-Maia and Engel (1949), and ourselves found two inversions, both of them in the same autosome (overlapping inversions). The mean frequency of heterozygous inversions per individual of $D$. bandeirantorum proved to be $0 \cdot 49 \pm 0 \cdot 02$. The material examined came from 4 populations in the State of São Paulo. In the 70 individuals of $D$. pallidipennis, from Pirassununga, in the State of São Paulo, examined by Freire-Maia and Engel (1949) and ourselves, the mean number of heterozygous inversions per individual proved to be even smaller, namely $0 \cdot 07 \pm 0 \cdot 04$. 


\section{DISCUSSION}

The data presented above are in a general agreement with the hypothesis that the amount of genetic variability present in a population is positively correlated with the number of ecological niches which this population exploits. Thus, the common and widespread species, $D$. polymorpha, has more heterozygous inversions per individual than its closest but less common relative, $D$. cardinoides. Similarly, the common $D$. guaramunu has more inversions than its less frequent relative, $D$. griseolineata. In $D$. nebulosa the populations which inhabit the ecologically limited and highly exacting desert environments show fewer inversions than do the inhabitants of richer and more diversified rain forest and savanna environments ( $c f$. da Cunha, Burla and Dobzhansky, I950).

Several reservations must, however, be made. In the first place, only closely related species, or races within a species, can profitably be compared. In different groups of organisms the genetic variability takes different forms, and chromosomal inversions are characteristic of the adaptive polymorphism in some sub-divisions of the animal and plant kingdoms but not in others. Even within the genus Drosophila, some species groups seem to be richer in inversions than others (thus, the subgenus Sophophora seems to have more inversions than the subgenus Drosophila). Some species have inversions in all chromosomes (e.g. D. willistoni and relatives, D. robusta, D. virilis), while other species have them concentrated in a single or in few chromosomes (e.g. D. pseudoobscura, D. persimilis, D. nebulosa).

Furthermore, given the present imperfect understanding of the ecology of Drosophila, our ability to evaluate the relative numbers of the adaptive niches controlled by a population is limited. By and large, an abundant and widespread species is likely to be ecologically more versatile than a rare one restricted to only few habitats. It stands, however, to reason that an ecologically specialised species may occur more commonly than an ecologically versatile one, provided that the special environment of the former is available in many places within a certain geographic region. Situations apparently contradictory to the hypothesis are, then, not unexpected, but, provided that the hypothesis is correct, they should be less frequent than situations conforming to the hypothesis. Such an apparent contradiction may be seen in table I. $D$. polymorpha has significantly more inversions per individual at Vila Atlantica than at Pirassununga or at Mogí das Cruzes. And yet this species reaches at times much higher frequencies at the latter than at the former localities. It may be significant in this connection, that the population size undergoes violent fluctuations at Pirassununga and at Mogi das Cruzes, reaching up to 22 per cent. of the total Drosophila catch during the summer, but becoming very rare during winter. At Vila Atlantica the population of $D$. polymorpha does not undergo such sharp expansions and contractions at different seasons. 


\section{SUMMARY}

Natural populations of several species of Drosophila were examined for the incidence of inversion heterozygotes among the individuals composing them. Inversion heterozygotes proved to be relatively more frequent in Drosophila polymorpha than in its close relative, Drosophila cardinoides, and more frequent in Drosophila guaramunu than in the neighbouring species, Drosophila griseolineata. Drosophila polymorpha and Drosophila guaramunu are more common and widespread in southern Brazil than are Drosophila cardinoides and Drosophila griseolineata. In Drosophila nebulosa, populations which inhabit ecologically rich and diversified environments of savannas and rain forests have more inversions than do geographically or ecologically marginal populations. These facts stand in accord with the hypothesis that the amount of adaptive polymorphism present in a population is positively correlated with the variety of environments which this population controls.

Acknowledgments.- The authors are much indebted to Prof. Th. Dobzhansky for his many suggestions and his help with the manuscript ; to Profs. C. Pavan and A. R. Cordeiro for the use of their unpublished data on the ecology and distribution of Drosophila in Brazil and for the many flies they have collected and furnished to the authors; to Dr $\mathbf{H}$. Burla who has examined a part of the slides of D. nebulosa ; to the many colleagues, and especially to Prof. H. L. Carson and Mrs Martha E. Breuer, for their help in the collection of the material used.

We are indebted to the Serviço de Rotas Aereas do Ministério da Aeronautica. for the use of their planes for the purposes of our collecting expeditions.

This work was carried out while two of us, D. Brncic and F. M. Salzano, held fellowships provided jointly by the Universidade de São Paulo and the Rockefeller Foundation. We are grateful to the Conselho Nacional de Pesquisas for the financial aid.

\section{REFERENCES}

BRNCIC, D. J. 1952. Chromosomal variation in natural populations of Drosophila guaramunu. Z.I.A.V. (in press).

DA CUNHA, A. B., BURLA, H., AND DOBZhansky, TH. I950. Adaptive chromosomal polymorphism in Drosophila willistoni. Evolution, 4, 2 1 2-235.

DOBZHANSKY, TH., BURLA, H., AND DA CUNHA, A. B. I950. A comparative study of chromosomal polymorphism in sibling species of the willistoni group of Drosophila. Amer. Nat., 84, 229-246.

DOBZHANSKY, TH., AND PAVAN, C. 1950. Local and seasonal variations in relative frequencies of species of Drosophila in Brazil. 7. Animal Ecology, I9, I-14.

FREIRE-MAIA, N., AND ENGEL, H. 1949. Variação cromosomica em Drosophila pallidipennis. Ciencia e Cultura, I, 204-207.

KING, J. C. 1947. A comparative analysis of the chromosomes of the guarani group of Drosophila. Evolution, $1,48-62$.

PATTERSON, J. T., AND DOBZHANSKY, TH. 1945. Incipient reproductive isolation between two subspecies of Drosophila pallidipennis. Genetics, 30, 429-438.

PATTERSON, J. T., AND WAGNER, R. P. 1943. Geographical distribution of species of the genus Drosophila in the United States and Mexico. Univ. Tcxas Publ., 4313, 21 7-282.

Pavan, c. 1946. Chromosomal variation in Drosophila nebulosa. Genetics, 3I, 546557. 